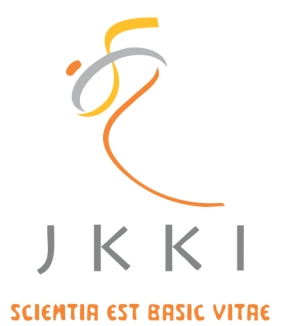

Jurnal Kedokteran dan Kesehatan Indonesia

Indonesian Journal of Medicine and Health

Journal homepage: https://journal.uii.ac.id/JKKI

\title{
Influences of oral cryotherapy on mucositis prevention in cancer patients with chemotherapy
}

\author{
Nataria Yanti Silaban*1, Siti Saidah Nasution², Cholina Trisa Siregar ${ }^{2}$ \\ ${ }^{1}$ Master Program, Faculty of Nursing, Universitas Sumatera Utara, Medan, Indonesia \\ ${ }^{2}$ Faculty of Nursing, Universitas Sumatera Utara, Medan, Indonesia
}

Original Article

\begin{tabular}{l}
\hline \\
\hline ART ICLE I NF O \\
\hline Keywords: \\
Oral cryotherapy, \\
mucositis, \\
cancer \\
chemotherapy \\
*Corresponding author: \\
nataria1612@gmail.com \\
\hline DOI: 10.20885/JKKI.Vol11.Iss2.art9 \\
History: \\
Received: March 11, 2020 \\
Accepted: August 6, 2020 \\
Online: August 31, 2020 \\
\hline Copyright @2020 Authors. \\
This is an open access article \\
distributed under the terms \\
of the Creative Commons At- \\
tribution-NonCommercial 4.0 \\
International Licence (http:// \\
creativecommons.org/licences/ \\
by-nc/4.0/).
\end{tabular}

\section{ABSTRACT}

Background: A mucositis is the most common problem in a chemotherapy treatment and becomes a severe problem for patients who receive several cycles of chemotherapy. Effects of an oral mucositis that is not treated immediately or is less effective can affect quality of life of the patients. Pain experienced by them can cause problems in the mouth, for example inability to tolerate food or fluids (dysphagia) and decreases of nutritional status.

Objective: This study is to identify effectiveness of oral cryotherapy on prevention of the mucositis in cancer patients with chemotherapy.

Methods: This study used a quasi-experimental method with a pre and post-test for a control group. Its samples were 32 patients for an intervention group and a control group, taken by using a consecutive sampling technique. The mucositis was measured by using questionnaires of Oral Assessment Guide (OAG), and the obtained data was analysed by the Wilcoxon and Mann Whitney test.

Results: This study found that 24 respondents were not affected by the mucositis at $p$-value $=0.008(\mathrm{p}<0.05)$ in the post intervention in the intervention group, and there was a difference in values of the mucositis measured by the $0 A G$ at $p$-value $=0.003(\mathrm{p}<0.05)$ in the post intervention in the both groups.

Conclusion: The oral cryotherapy could prevent the mucositis in cancer patients with chemotherapy.

Latar Belakang: Mukositis merupakan masalah yang paling umum dalam pengobatan kemoterapi dan menjadi masalah yang sangat serius bagi pasien yang menerima beberapa siklus pengobatan kemoterapi. Efek penanganan mukositis oral yang tidak segera ditangani atau kurang efektf akan mempengaruhi kualitas hidup pasien. Rasa sakit yang dialami pasien menyebabkan ketidaknyamanan pada mulut, ketidakmampuan untuk mentoleransi makanan dan cairan (disfagia) dan sampai akhirnya mengalami penurunan status gizi.

Tujuan: Untuk mengidentifikasi efektivitas cryotherapy oral pada pencegahan dari mucositis pada pasien kanker yang sedang menjalani kemoterapi.

Metode: Penelitian ini menggunakan metode eksperimen semu dengan pre-post test dengan kelompok kontrol. Sampel adalah 32 pasien untuk kelompok intervensi dan kelompok kontrol, diambil dengan menggunakan teknik consecutive sampling. Mucositis diukur dengan menggunakan kuesioner pada Oral Assessment Guide (OAG) sedangkan data dianalisis dengan uji Wilcoxon dan uji Mann Whitney.

Hasil: Hasil menunjukkan, dalam post intervensi pada kelompok intervensi, 24 responden tidak terpengaruh oleh mucositis pada p-value $=0.008$ ( $p<0.05)$; dalam pasca intervensi pada kedua kelompok, ada perbedaan 
dalam nilai mucositis yang diukur dengan OAG pada $p$-value $=0.003(p<0.05)$.

Kesimpulan: Cryotherapy oral dapat mencegah mucositis pada pasien kanker yang sedang menjalani kemoterapi.

\section{INTRODUCTION}

Cancer is the second leading cause of death after cardiovascular diseases in the world. According to a report by the International Agency for Research on Cancer (IARC) in 2012, an estimated incidence of cancer in the world would be14.1 million for new cases and 8.2 million for cases of death. Lung cancer still leads the rank of the highest incidence rate (1.82 million) followed by breast cancer (1.67 million) and colorectal (1.36 million). The highest-ranking causes of death are lung cancer (1.6 million) and followed by liver cancer $(745,000)$ and stoma cancer $(723,000) .{ }^{1}$ Data from Indonesia basic health research (RISKESDAS) in 2013 stated that cancer prevalence in Indonesia is $14 \%$ or is estimated to be about 347,792 people. In fact, Province of D.I. Yogyakarta has the highest prevalence of cancer, about $41 \%{ }^{2}$

According to Komite Nasional Penanggulangan Kanker/national committee for cancer management (KPKN), there are various types of cancer treatment therapies including surgery, radiation therapy, chemotherapy, hormonal therapy, and immune therapy. The therapies can be given in one type or in combination depending on stages of cancer, tumour characteristics, age, health, and preferences of patients more than half of cancer patients are treated by chemotherapy. ${ }^{3}$ Chemotherapy is a type of therapy to kill cancer cells and is the most effective therapy for cancer patients. The therapy given to cancer patients aims to cure the cancer, prolong life and improve the quality of life. ${ }^{3,4}$

The chemotherapy can cause side effects such as fatigue, nausea, vomiting, anorexia, myelosuppression, hair loss, mucositis, and death in severe cases, but a side effect that often occur in patients undergoing chemotherapy are the mucositis. ${ }^{4,5}$

Early intervention for oral mucositis is crucial.
In this case, roles of nurses are needed because more nurse' time in providing services can provide immediate care according to patients' condition. Besides, nurses are responsible for managing chemotherapy schedules. Interventions for the mucositis need to be conducted according to the chemotherapy schedules, and the nurses are the most appropriate people to deal with these treatments. The oral mucositis occurs about 7 to 14 days after the chemotherapy. ${ }^{6}$ The majority of patients require chemotherapy treatment every two weeks. Patients who experience a mucositis in a previous chemotherapy cycle that is not treated immediately will experience an increase of mucositis levels in the next chemotherapy cycle.

Martin and Perez stated that oral mucositis treatment could be also conducted with oral hygiene protocols, chlorhexidine digluconates, cytoprotective agents (amifostine, sucralfate, glutamine, allopurinol, cryotherapy, growth factors, and Low-Level Laser Therapy/LLLT). ${ }^{7}$

Intraoral cooling therapy or oral cryotherapy had previously been reported to be effective for chemotherapy-induced mucositis. ${ }^{8} \mathrm{~A}$ cochrane review reported that oral cryotherapy could reduce oral mucositis of any severity in adult patients undergoing fluorouracil-based chemotherapy for solid cancers. ${ }^{9}$ Studies have suggested that cryotherapy can decrease a burden of chemotherapy-related to oral mucositis. ${ }^{10}$

Based on the previous studies above, this study aims to determine whether there is an effect of oral cryotherapy on decreasing levels of mucositis in cancer patients undergoing chemotherapy.

\section{METHODS}

This study was a quasi-experimental research with a pre and post test for a control group. This study was conducted in the Adam Malik General Hospital Medan on January 2018 to April 2019. Sixty four respondents were involved in this study by using a consecutive sampling. Inclusion criteria in this study were: 1 ) patients who were aged 18-65 years old; 2) patients who 
took chemotherapy treatment for the first time; 3) patients who suffered Ca Nasopharynx; 4) mucositis that had not occurred; 5) patients who had no sensitivity to ice; 6) patients who wanted to be respondens in this study; 7) respondents were fully aware and able to answer questions; 8) patients who had excellent communication

This study applied the Oral Assessment Guide (OAG) and observation sheets of documentation in implementing the oral cryotherapy. Oral examination by using the OAG was conducted by clinical assessments including sound, swallow, lips, tongue, saliva, mucous membranes, gums, and teeth. This test had scores from 1 to 3 for each of 8 categories. A score of 1 indicated a normal condition, a score of 2 indicated a minor change in functions, and a score of 3 indicated a high damage and loss of functions of that aspects. Then the scores was added to produce mucositis scores from 8-24. The Royal Children's Hospital Australia categorized the OAG into three categories, namely category 1 with an OAG score of 8 (normal), category 2 with an OAG score of 9-16 (mild-moderate), and category 3 with an OAG score in the range 17-24 (severe mucositis). The numbers were categorized into two categories, namely no mucositis at an OAG score $<10$ and mucositis at an OAG score $\geq 10$. $^{11}$ The OAG was applied because this instrument is commonly used to measure levels of mucositis and is easy to aplly or assess.

Observation sheets in implementating the oral cryotherapy were a tool used to observe the implementation of oral cryotherapy by protocols that had been made. Checking the checklist $(\sqrt{ })$ on the observation sheets was when researchers performed according to the protocols. Putting a dash (-) on the observation sheets when the researchers did not perform according to the protocols.

A bivariate analysis in this study was used by a Wilcoxon Signed Rank test. This test was to determine differences of mucositis scores before and after oral cryotherapy in each intervention group, while a Mann-Whitney U test was used to determine differences of mucositis scores between the intervention and control group.
The conceptual framework

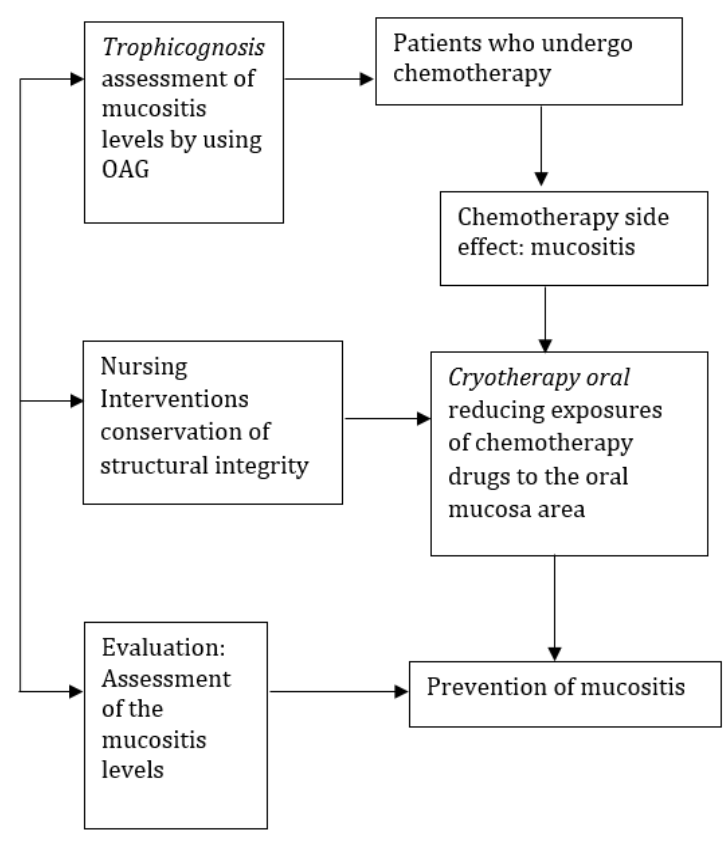

\section{Ethical Consideration}

This study was approved by The Research Ethics Committee, Faculty of Nursing, Universitas Sumatera Utara No. 1577/X/ SP/2018.

\section{RESULTS}

Table 1. shows that an average of age of respondents in this study was $44.00 \pm 5,067$ in the intervention group and $44.13 \pm 4,784$ in the control group. Based on age grouping, the respondents were in a range of 35-54 years old, namely $71.9 \%$ in the intervention group and $96.9 \%$ in the control group. Based on gender, the respondents were dominated by men by $68.8 \%$ in the intervention group and $68.2 \%$ in the control group. Based on educational background, the respondents who graduated from high school were $71.9 \%$ in the intervention group and 7\% in the control group. There were $81.3 \%$ of respondents working as entrepreneurs in the intervention group and $81.5 \%$ in the control group. Based on marital status, $90.6 \%$ were married in the intervention group and $87.5 \%$ in the control group. Most of ethnics in this study were from the Batak, namely $75.0 \%$ in the intervention group and $71.9 \%$ in the control 
group. For the chemotherapy cycle, the majority

group and $58.3 \%$ in the control group.

of the first cycle was $71.9 \%$ in the intervention

Table 1. Characteristics of respondents

\begin{tabular}{|c|c|c|c|c|c|}
\hline \multirow[t]{2}{*}{ No. } & \multirow[t]{2}{*}{ Variables } & \multicolumn{2}{|c|}{ Intervention group $(n=32)$} & \multicolumn{2}{|c|}{ Control group $(n=32)$} \\
\hline & & f & $\%$ & f & $\%$ \\
\hline \multirow[t]{5}{*}{1} & Age & & & & \\
\hline & & Mean: 44.00 & SD : 5.607 & Mean: 44.13 & SD: 4.784 \\
\hline & 18-34 years & 4 & 12.5 & 1 & 3.1 \\
\hline & $35-54$ years & 23 & 71.9 & 31 & 96.9 \\
\hline & $55-64$ years & 5 & 15.6 & 0 & 0 \\
\hline \multirow[t]{3}{*}{2} & Sex & & & & \\
\hline & Male & 22 & 68.8 & 24 & 75.0 \\
\hline & Female & 10 & 31.3 & 8 & 25.0 \\
\hline \multirow[t]{4}{*}{3} & Education & & & & \\
\hline & Junior High School & 1 & 3.1 & 5 & 15.6 \\
\hline & Senior High School & 23 & 71.9 & 24 & 75.0 \\
\hline & College & 1 & 25.0 & 3 & 9.4 \\
\hline \multirow[t]{5}{*}{4} & Employment & & & & \\
\hline & Civil officer & 1 & 3.1 & 0 & 0 \\
\hline & Entrepreneur & 26 & 81.3 & 26 & 81.5 \\
\hline & Housewife & 2 & 6.3 & 5 & 15.6 \\
\hline & No working & 3 & 9.4 & 1 & 3.1 \\
\hline \multirow[t]{3}{*}{5} & Marital status & & & & \\
\hline & Married & 29 & 90.6 & 28 & 87.5 \\
\hline & Widow & 3 & 9.4 & 4 & 12.5 \\
\hline \multirow[t]{5}{*}{6} & Ethnic & & & & \\
\hline & Batak & 24 & 75.0 & 23 & 71.9 \\
\hline & Java & 4 & 12.5 & 6 & 18.8 \\
\hline & Aceh & 1 & 3.1 & 0 & 0 \\
\hline & Malay & 3 & 9.4 & 3 & 9.4 \\
\hline \multirow[t]{4}{*}{7} & Income & & & & \\
\hline & $<1$ million/monthly & 29 & 90.6 & 29 & 90.6 \\
\hline & $>1-2$ million/monthly & 1 & 3.1 & $\checkmark 1$ & 3.1 \\
\hline & $>2$ million/monthly & 2 & 6.3 & 2 & 6.3 \\
\hline \multirow[t]{4}{*}{8} & Chemotherapy cycle & & & & \\
\hline & cycle 1 & 23 & 78.1 & 18 & 56.3 \\
\hline & cycle 2 & 4 & 6.3 & 7 & 21.9 \\
\hline & cycle 3 & 5 & 15.6 & 7 & 21.9 \\
\hline
\end{tabular}


Table 2 shows that the mucositis value in the intervention group before treatment had an $O A G$ value $<10$ for 32 respondents and had an $O A G$ value $<10$ for 29 respondents after the intervention and for 3 respondents with an
OAG value $\geq 10$. OAG values of all respondents in the control group before treatment and after treatment were $<10.12$ respondents with $\mathrm{OAG}$ values $<12$, and 18 respondents were with $\mathrm{OAG}$ values $\geq 10$.

Table 2. mucositis values of the intervention and control group of cancer patients with chemotherapy

\begin{tabular}{lcccccccc}
\hline \multirow{3}{*}{ Variable } & \multicolumn{4}{c}{ Pre } & \multicolumn{4}{c}{ Post } \\
\cline { 2 - 9 } & \multicolumn{2}{c}{ No mucositis } & \multicolumn{2}{c}{ Mucositis } & No mucositis & Mucositis \\
\cline { 2 - 9 } & $\mathbf{f}$ & $\mathbf{0}$ & $\mathbf{f}$ & $\mathbf{\%}$ & $\mathbf{f}$ & $\mathbf{\%}$ & $\mathbf{f}$ & $\mathbf{\%}$ \\
\hline Intervention group & 32 & 100 & 0 & 0 & 29 & 88.6 & 3 & 9.3 \\
Control group & 32 & 100 & 0 & 0 & 12 & 37.3 & 18 & 63,9 \\
\hline
\end{tabular}

Table 3 shows that there were differences of mucositis values between before and after the oral cryotherapy measured by OAG after statistically tested by using the Wilcoxon
Signed Rank test with a mean rank of 4.50 and $\mathrm{p}=0.008(\mathrm{p}<0.05)$. Then in the control group, the mean rank was 12.06 with $\mathrm{p}=0.003$ $(\mathrm{p}<0.05)$.

Table 3. Average scores of eight dimensions in the SF-36 (n=13)

\begin{tabular}{ccccccc}
\hline Variable & \multicolumn{2}{c}{ Intervention group (N=32) } & \multicolumn{3}{c}{ Control group (N=32) } \\
\hline \multirow{2}{*}{$(\mathrm{OAG})$ value } & Mean Rank & $\mathrm{Z}$ & $\mathrm{p}$-value & Mean Rank & $\mathrm{Z}$ & $\mathrm{p}$-value \\
& 4.50 & -2.640 & 0.008 & 12.06 & -4.238 & 0.000 \\
\hline
\end{tabular}

Table 4 shows that there were differences of $\quad$ and the control group with $\mathrm{p}=0.003(\mathrm{p}<0.05)$. mucositis values between the intervention group

Table 4. differences mucositis values in the intervention and control group based on the Mann-Whitney u test

\begin{tabular}{lccc}
\hline Variable & $\begin{array}{c}\text { Median } \\
\text { (Minimal-Maximal) }\end{array}$ & Z-value & p-value \\
\hline OAG value & 9.00 & $-3,007$ & 0.003 \\
& $(8-14)$ & & \\
\hline
\end{tabular}

\section{DISCUSSION}

Results of this study indicated that the number of respondents who did not experience mucositis was higher in the intervention group than in the control group. This difference was because respondents in the intervention group conducted the oral cryotherapy, a treatment designed during their chemotherapy. Also, this study showed that the oral cryotherapy in the intervention group was more effective to prevent the mucositis. It can be concluded that the oral cryotherapy can prevent the mucositis in cancer patients with chemotherapy.

These results of this study are in line with Katrancl, Ovayolu, Ovayolu, and Sevinc's study finding that oral cryotherapy could affect protection of oral health by reducing mucositis scores according to the WHO scale, especially on the $7^{\text {th }}$ and $14^{\text {th }}$ day. Oral mucositis is a common effect caused by a cancer treatment that can cause mucosal toxicity. Patients with oral mucositis experience severe pain and are 
unable to eat, drink, and talk; as a result, their quality of life is impaired. ${ }^{12} 30-80 \%$ of patients undergoing chemotherapy will experience oral mucositis. Preventing or reducing incidences of the oral mucositis and its severity can help reducing pain experienced by the patients. Oral cryotherapy is a prophylactic intervention to reduce the incidences and severity of oral mucositis induced by chemotherapy. ${ }^{13}$

A study conducted by Svanberg stated that oral cryotherapy could significantly delay the incidences and severity of mucositis among patients treated by myeloblative therapy before bone marrow transplantation, and it could reduce numbers of od days with i.v. opioids. ${ }^{14}$

Based on Wilcoxon test results, this study demonstrated that there were differences in the pre and post mucositis assessment of gargling with normal saline by a value of $\mathrm{p}=0.000$. These are similar to a study conducted by Nursalam, Ertawati, and Kristyaningsih, stating that the $\mathrm{p}$-value was 0.012 in the normal saline group; normal saline is effective to prevent the oral mucositis. The normal saline is a physiological fluid (according to body fluids) that functions to clean debris, does not irritate, nor does it change the $\mathrm{pH}$ of saliva. Because it does not change the $\mathrm{pH}$ of saliva, a natural buffer of the mouth will not be disturbed. The physiological mouth will be maintained because there is no irritation. ${ }^{15}$ Reducing a number of debris will reduce bacteria in the mouth. If a patient rinses with normal saline, it is expected that endurance (oral) of the patient will increase. ${ }^{16}$

The value of mucositis before and after the oral cryotherapy in this study was identified by comparing the post-test values of the mucositis levels between the intervention group and the control group by using a statistical analysis of the Mann Whitney test. Based on the analysis, it could be interpreted that there were differences in the intervention and control group with an OAG value, $p=0.003$, given $p<0.05$.

The results are in line with a study by Askarifar, Lakdizaji, Ramzi, Rahmani, and Jabbarzadeh, which divided the two groups: the intervention group with oral cryotherapy and the control group by using normal saline. The results showed that on the $7^{\text {th }}$ day, the severity of mucositis was less in the intervention group $(\mathrm{p}=0.031)$ than in the control group. On the $14^{\text {th }}$ day, the mucositis severity was less in the intervention group $(\mathrm{p}=0.004)$ than in the control group. The study concluded that cryotherapy was more effective than mouthwash by using normal saline in preventing the mucositis. ${ }^{4}$

In addition, Karagozoglu and Ulusoy found that the incidences of mucositis in the intervention group were $10 \%$, and in the control group, $50 \%$ using instruments measuring the degree of mucositis Physician-Judged Mucositis Grading. The results of the study confirmed that oral cryotherapy was adequate to prevent mucositis and effective to reduce its severity. ${ }^{16}$

\section{CONCLUSION}

The results of this study found oral cryotherapy to prevent the mucositis in cancer patients undergoing chemotherapy was effective.

\section{CONFLICT OF INTEREST}

There was no conflict of interest.

\section{ACKNOWLEDGEMENT}

None declare.

\section{REFERENCES}

1. International Agency for Research on Cancer (IARC). No Title [Internet]. 2012. Available from: http://globocan.iarc.fr/Default. aspx.

2. (RISKESDAS) RKD. No Title [Internet]. 2016. Available from: http://terbitan.litbang.depkes.go.id/penerbitan/index.php/ $\mathrm{lpb} /$ catalog/book/158.

3. Society AC. No Title [Internet]. 2017. Available from: https://www.cancer.org/research/cancer-facts-statistics/all-cancerfacts-figures/cancer-facts-figures-2017. html.

4. Askarifar M, Lakdizaji S, Ramzi M, Rahmani A, Jabbarzadeh $F$. The effects of oral cryotherapy on chemotherapy-induced oral mucositis in patients undergoing autologous transplantation of blood stem cells: A 
clinical trial. Iranian Red Crescent Medical Journal. 2016;18(4).

5. Cidon EU. Chemotherapy induced oral mucositis: Prevention is possible. Chinese Clinical Oncology. 2018;7(1).

6. Gori E, Arpinati M, Bonifazi F, Errico A, Mega A, Alberani F, et al. Cryotherapy in the prevention of oral mucositis in patients receiving low-dose methotrexate following myeloablative allogeneic stem cell transplantation: A prospective randomized study of the Gruppo Italiano Trapianto di Midollo Osseo nurses group. Bone Marrow Transplant. 2007;39(6):347-52.

7. Alvariño-Martín C, Sarrión-Pérez MG. Prevention and treatment of oral mucositis in patients receiving chemotherapy. Journal of Clinical and Experimental Dentistry. 2014;6(1):74-80.

8. Okamoto K, Ninomiya I, Yamaguchi T, Terai S, Nakanuma S, Kinoshita J, et al. Oral cryotherapy for prophylaxis of oral mucositis caused by docetaxel, cisplatin, and fluorouracil chemotherapy for esophageal cancer. Esophagus. 2019;16(2):207-13.

9. Riley P, Glenny AM, Worthington H V., Littlewood A, Clarkson JE, Mccabe MG. Interventions for preventing oral mucositis in patients with cancer receiving treatment: Oral cryotherapy. Cochrane database of systematic reviews. 2015;2015(2):9-10.

10. Nawi RIM, Chui PL, Wan Ishak WZ, Hsien Chan CM. Oral cryotherapy: Prevention of oral mucositis and pain among patients with colorectal cancer undergoing chemotherapy. Clinical Journal of Oncology Nursing. 2018;22(5):555-60.

11. Mubaraki S. Oral mucositis in children associated with hematopoietic stem cells transplant. Saudi Journal of Oral Sciences. 2019;6(2):47.

12. Katranci N, Ovayolu N, Ovayolu O, Sevinc A. Evaluation of the effect of cryotherapy in preventing oral mucositis associated with chemotherapy - A randomized controlled trial. European Journal of Oncology Nursing. 2012;16(4):339-44.

13. Peterson DE, Öhrn K, Bowen J, Fliedner M, Lees J, Loprinzi C, et al. Systematic review of oral cryotherapy for management of oral mucositis caused by cancer therapy. Support Care Cancer. 2013;21(1):327-32.

14. Svanberg A, Birgegård G, Öhrn K. Oral cryotherapy reduces mucositis and opioid use after myeloablative therapy - A randomized controlled trial. Support Care Cancer. 2007;15(10):1155-61.

15. Caplinger J, Royse M, Martens J. Implementation of an Oral Care Protocol to promote early detection and management of stomatitis. Clinical Journal of Oncology Nursing. 2010;14(6):799-802.

16. Karagözoğlu Ş, Ulusoy MF. Chemotherapy: The effect of oral cryotherapy on the development of mucositis. Journal of Clinical Nursing. 2005;14(6):754-65. 